\title{
Experimental Study of Inclined Bridge Pier Scouring
}

\author{
Fakhar Muhammad Abbas $^{1 \mathrm{a}}$, Usman Ali Naeem ${ }^{1 \mathrm{~b}}$, Usman Ghani1 ${ }^{1 \mathrm{c}}$, Talat Farid Ahmad ${ }^{2}$, \\ Amina ${ }^{1 d}$
}

RECEIVED ON 19.12.2018, ACCEPTED ON 26.07.2019

\section{ABSTRACT}

The bridges are one of important structures in any country. The failure of bridges occurs due to many factors including design flaws and manufacturing construction errors. Among all imperfections scouring around the pier is the most detrimental. So, the estimation of local scouring around a bridge pier is of fundamental importance for the safe design of bridges. Although numerous researches have been done on local scouring around a single bridge pier. The present study investigates the effect of angle of inclination of dual bridge pier configuration on local scouring around bridge piers. Principally rectangular shaped dual bridge piers were installed in sand bed of laboratory flume at angle of inclination of $0^{\circ}, 7^{\circ}, 12^{\circ}, 15^{\circ}$ and $19^{\circ}$ with vertical respectively. Three different flow rates 9,14 and $18 \mathrm{~L} / \mathrm{sec}$ were considered during each trial. The duration of each trial was kept around 2 hours. The scour depth was measured separately around both piers with the help of point gauge under clear water condition. The value of scour depth around upstream pier was larger as compared to downstream pier because of the lower strength of horseshoe vortices around downstream pier. From the experimental results, it can be concluded that there is an inverse relationship between the angle of inclination and scour depth, an increase in the angle of inclination leads to decrease in scour depth around both piers. The value of scour depth was maximum when piers were at $0^{\circ}$ and minimum at $19^{\circ}$. It was also found that scour depth increases with the increase in flow rate.

Keywords: Bridge Pier, Inclined Bridge Piers, Local Scouring, Flow Rate.

\section{INTRODUCTION}

Scouring is a process in which removal of sediments such as sand and gravel occurs from abutments and piers of bridges. Karimi, et al. [1] stated that bridge piers and abutments existing across the river decrease the cross section of water flow. When the swiftly flowing water strike these piers and supports the streamlines of flowing water are diverted towards river bed floor and create horseshoe, swirling and rising vortices. These vortices are main cause of local scouring around bridge piers. This local scour results in the exposure of foundation, which leads towards bridge failure. Many researchers have studied the scouring process theoretically and experimentally using different shapes of piers and many parameters affecting this phenomenon. According to Briaud et al. [2], more than 1000 bridge failure reported in the United States and $60 \%$ of these failures were due to local scouring. Shirole and Holt [3] studied and demonstrated 283 bridge failures, most of these failures were due to phenomena of scouring. Bozkus et al. [4] found that scouring around inclined pier was smaller as compared to vertical piers. The scour rate was higher in early stage of experiment while it decreases with the passage of time and scour depth at upstream side of pier was larger as compared to downstream side.

\footnotetext{
${ }^{1}$ Department of Civil Engineering, University of Engineering and Technology, Taxila, Pakistan.

Email: ${ }^{\mathrm{a}} \mathrm{mr}$ _fakharababs@yahoo.com (Corresponding Author), ${ }^{\mathrm{b}}$ usman.naeem@uettaxila.edu.pk, usman.ghani@uettaxila.edu.pk, ${ }^{\mathrm{d}}$ Amina168civil@gmail.com

${ }^{2}$ Principal Scientific Officer, NARC, Islamabad, Pakistan. Email: Tafa367@ gmail.com

This is an open access article published by Mehran University of Engineering and Technology, Jamshoro under CC BY 4.0 International License.
} 
Heidarnejad et. al. [5] investigated that slots can be used to reduce the pier scouring in 180-degree river bend. This study indicated that application of slots for reduction of scour depth decreases with the increase in the proportion of the average flow velocity to threshold velocity of sediments movement. Kumar et. al. [6] explained that scour depth and its temporal variation is also dependent on the variation of foundation and pier geometry. In the study compound piers were used, and it was indicated that by changing the elevation of top surface of foundation the scour depth is also changed. The maximum scour depth is reduced when the top surface of the well is below the general level of river bed in comparison to the maximum scour depth caused by the pier alone.

Debnath and Chaudhuri [7] stated that maximum equilibrium scour depth in clay beds is similar to that of sand, while increase in the clay fraction for claysand mixed beds reduced maximum equilibrium scour depth. Guo et al. [8] found that scouring around pier is also dependent on time. The scour depth increases as time increases until equilibrium state is achieved while shape of longitudinal profile does not change with respect to time.

Kitsikoudis et al. [9] stated that the scour depth is reduced with increase in pile inclination. Reduction in scour depth is about $50 \%$ whereas scour volume decreases $73 \%$ when pile inclination is 42 . Zhao and Cheng [10] investigated experimental and numerical study of local scour around a submerged vertical circular cylinder. It was indicated that scour depth is reduced with reduction in height of cylinder. The result of numerical model was $10-20 \%$ smaller than those measured in experiments.

Vaghefi et al. [11] presented an experimental study of circular bridge pier with different angles of inclination, with an increase in the angle of inclination the scour depth is reduced. Mohammed et al. [12] stated that local scour depth around the pier is reduced by usage of collar, current deflector and sacrificial pile and upstream piers. Hamidi and Siadatmousavi [13] presented numerical model to check the scouring pattern around pier. The results showed that there was consistency in scouring pattern near each pile, and the deep scouring pattern was established between two piers after some time.

Guan et. al. [14] investigated that horseshoe vertices are formed in front of pier that develop scouring pattern and size of these vortices increases with increasing scour depth. Moussa [15] investigated scouring around pier by applying CCHE-2D and HEC-RAS 5 1-D models to Aswan and El Minia bridges and concluded that scouring at Aswan Bridge is higher due to big dimensions of piers than El-Minia bridge. It was found that scouring is smallest at sharp nosed piers at normal flow to the pier.

Karimi et al. [1] presented experimental study to examine scour depth by using cylindrical piers with different inclination angles and concluded that the scour depth was maximum at inclination angle $0^{\circ}$ and minimum at $15^{\circ}$ while the size and depth of scoured hole decreased with increasing angle of inclination. Murtaza et al. [16] investigated experimentally that scour depth was minimum around octagonal pier and maximum around square shape pier while in case of circular and oval faced scour depth was intermediate as compared to square and octagonal bridge pier. Elnikhely [17] stated that the reduction in scour depth was $80 \%$ by using perforated pile for angle $45^{\circ}$ while the scour reduction for perforated pile was $47 \%$ at angle $90^{\circ}$.Scour depth at $0^{\circ}$ around perforated pile was greater than at $90^{\circ}$ and $45^{\circ}$. Ghani and Ali [18] presented numerical model to investigate flow variables around piers. It was observed that with increase in discharge the turbulence at downstream side of pier was also increased. Amir et. al. [19] Stated that vegetation was proved best tool for reduction of scouring. There was $39 \%$ reduction in scour depth in case of vegetated banks as compared to unvegetated banks at a flow rate of $0.04 \mathrm{~m}^{3} / \mathrm{sec}$.

Failure of bridges during the flood leads to disorder in transportation systems and may cause loss of life and properties. Therefore, scouring consideration in the design of bridges is an important issue. So, it is necessary to calculate the scour depth at bridge pier to control and reduce the bridge failure. Although a lot of research have been done for estimation of scour depth around pier but there is need to investigate the techniques for scour reduction around bridge pier. 
From the previous studies it can be seen that one of important technique for scour reduction is by providing inclined bridge pier. Single inclined bridge pier has been used in previous research to investigate the effect of inclination on scour depth. In present study two inclined rectangular piers (upstream pier and downstream pier) with different angle of inclination and varying flow rates, are used simultaneously to investigate the variation in scouring pattern around both piers under clear water condition to check their reliability for safe design of future bridges.

\section{MATERIALS AND METHOD}

To study the local scouring around inclined bridge piers the experiments were conducted in laboratory flume. Laboratory flume was $20 \mathrm{~m}$ long, $1 \mathrm{~m}$ wide and $0.75 \mathrm{~m}$ deep open channel. The whole channel was made of concrete, but the walls of the channel were made of glass. Water was released into the channel through the pipe by a pump that carries water in an overhead tank from an underground storage. The flow was controlled with a valve installed ahead of the channel as shown in Fig. 1(a-b). In the initial stage of the experiment, water was pumped in a channel at a very slow rate to avoid disturbance in bed material. A plastic sheet was used to make flow uniform up to a $5 \mathrm{~m}$ length of the channel. The flow velocity was measured with a velocity sensor, and flow depth was measured with point gauges. Yanmaz and Kose [20] investigated that if standard deviation $\delta_{\mathrm{g}}<1.30$ then sand will be uniform. The sand used in this study was uniformly graded, having $\mathrm{D}_{50}=0.28$, specific gravity 2.79. Geometric standard deviation $\left(\delta_{\mathrm{g}}\right)=1.21$ was used as bed material up to a $10 \mathrm{~m}$ length of the channel. The sand bed was perfectly horizontal with a thickness of $30.48 \mathrm{~cm}$. Before starting each trial of the experiment, the bed was properly levelled. Configuration of wooden made dual rectangular pier were tested at five different inclination angles of $0^{\circ}, 7^{\circ}$, $12^{\circ}, 15^{\circ}$ and $19^{\circ}$ with vertical as shown in Fig. 2(a-b). The scouring pattern of both piers was measured around upstream face, downstream face, left face, right face, upstream diagonal face and downstream diagonal face respectively as shown in Fig. 3. Maximum duration of each trial was 2 hours. Chiew and Melville [21] stated that $80 \%$ of equilibrium scour depth was achieved after $10 \%$ of equilibrium time. The flow rate was measured with compound rectangular- trapezoidal sharp-crested weir as shown in Fig. 4. Three different flow rates 9, 14, and $18 \mathrm{~L} / \mathrm{s}$ were used in experiments.

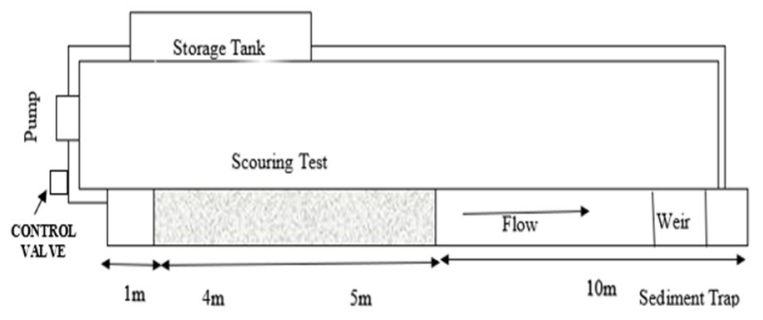

Fig. 1(a): Top View of Laboratory Flume

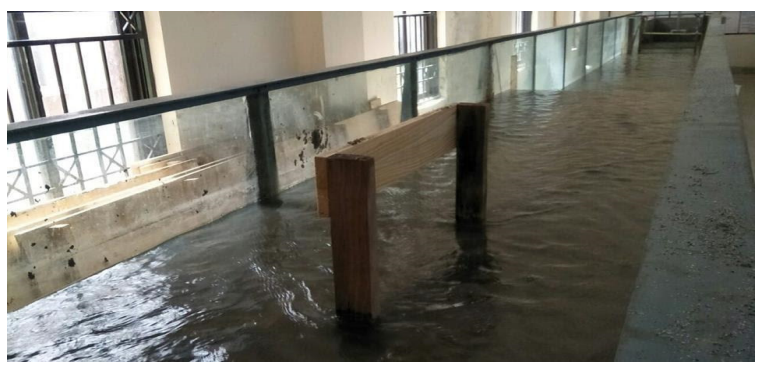

Fig. 1(b): Two Rectangular Piers Layout

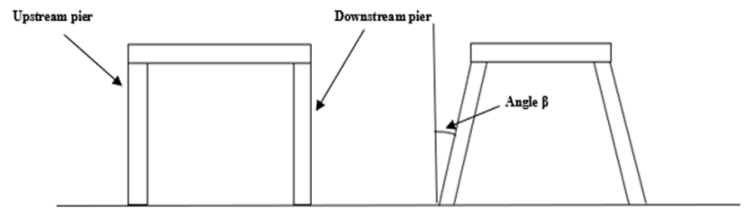

Fig. 2(a): Two Rectangular Piers Layout

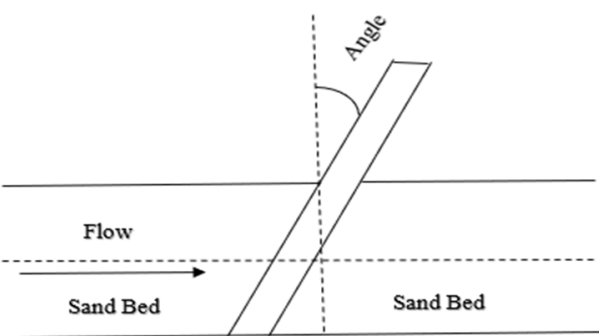

Fig. 2(b): Inclined Rectangular Pier Position Inside Flume

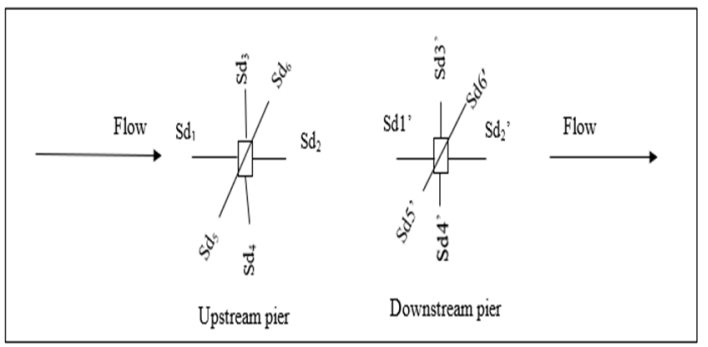

Fig. 3: Pattern Scour Measurement around two Rectangular Piers 


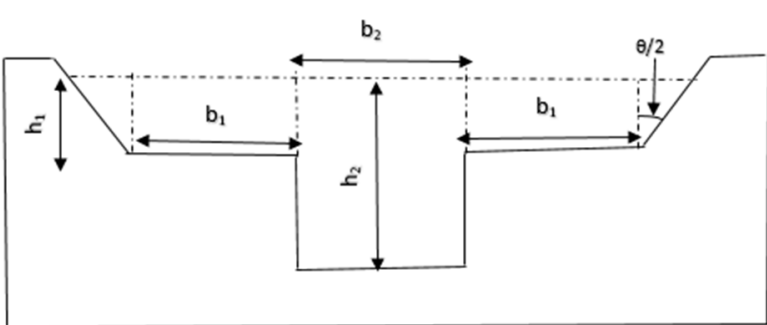

Fig. 4: Compound Rectangular-Trapezoidal Sharp-Crested Weir

The desired flow rate used in experiments was adjusted by varying over the weir. The values of discharges were calculated by Equation (1) of Compound rectangular-trapezoidal sharp-crested weir [22].The discharge values are shown in Table 1.

$$
\begin{aligned}
\mathrm{Q}= & \frac{2}{3} \mathrm{C}_{\mathrm{rd} 2} \sqrt{2 \mathrm{~g} \mathrm{~b}_{2}} \mathrm{~h}_{2}^{\frac{3}{2}}+\frac{2}{3} \mathrm{C}_{\mathrm{rd} 1} \sqrt{2 \mathrm{~g}}\left(2 \mathrm{~b}_{1}\right) \mathrm{h}_{1}^{\frac{3}{2}} \\
& +\frac{8}{15} \mathrm{C}_{\mathrm{td}} \sqrt{2 \mathrm{~g}} \tan \left(\frac{\theta}{2}\right) \mathrm{h}_{1 \mathrm{e}}^{\frac{5}{2}}
\end{aligned}
$$

where $b$ is weir length, $g$ is gravitational acceleration, $\mathrm{C}_{\mathrm{rd}}$ is discharge coefficient of the rectangular sharpcrested weir, $\mathrm{C}_{\mathrm{td}}$ is discharge coefficient for triangular sharp-crested weir, $h$ is water head on the weir crest $h_{e}$ is effective head $\mathrm{z}, \theta$ wis notch angle

\begin{tabular}{|c|c|c|c|c|c|c|c|c|}
\hline $\begin{array}{l}\text { Upstream } \\
\text { Pier }\end{array}$ & $\begin{array}{c}\text { Angle } \\
(\beta)\end{array}$ & $\begin{array}{c}\mathrm{Q} \\
(\mathrm{L} / \mathrm{sec}) \\
\end{array}$ & $\begin{array}{l}\mathrm{Sd} 1 \\
(\mathrm{~cm}) \\
\end{array}$ & $\begin{array}{l}\mathrm{Sd} 2 \\
(\mathrm{~cm})\end{array}$ & $\begin{array}{l}\mathrm{Sd} 3 \\
(\mathrm{~cm})\end{array}$ & $\begin{array}{l}\mathrm{Sd} 4 \\
(\mathrm{~cm}) \\
\end{array}$ & $\begin{array}{l}\mathrm{Sd} 5 \\
(\mathrm{~cm})\end{array}$ & $\begin{array}{l}\text { Sd6 } \\
(\mathrm{cm})\end{array}$ \\
\hline $\mathrm{P} 1$ & \multirow{3}{*}{0} & 9 & 7.2 & 4.6 & 6.9 & 6.3 & 6.9 & 5.5 \\
\hline $\mathrm{P} 1$ & & 14 & 9 & 5.5 & 8.2 & 8.4 & 7.7 & 7.1 \\
\hline $\mathrm{P} 1$ & & 18 & 10.4 & 6 & 9.6 & 9.1 & 8.9 & 7.8 \\
\hline $\mathrm{P} 1$ & \multirow{3}{*}{7} & 9 & 5.9 & 3.2 & 5.2 & 5 & 5.6 & 4 \\
\hline P1 & & 14 & 8.1 & 4.5 & 7.2 & 7 & 7.1 & 6.5 \\
\hline P1 & & 18 & 8.8 & 5 & 8.1 & 8 & 8 & 7 \\
\hline P1 & \multirow{3}{*}{12} & 9 & 5 & 1.9 & 4.7 & 4.5 & 4.9 & 3.4 \\
\hline P1 & & 14 & 7 & 3.5 & 6.6 & 6.3 & 6.4 & 5.7 \\
\hline $\mathrm{P} 1$ & & 18 & 7.6 & 4 & 7 & 6.9 & 7.3 & 6 \\
\hline P1 & \multirow{3}{*}{15} & 9 & 4.3 & 1.4 & 3.8 & 3.6 & 4 & 2.8 \\
\hline $\mathrm{P} 1$ & & 14 & 6.4 & 2.9 & 5.7 & 5.6 & 5.3 & 4.8 \\
\hline P1 & & 18 & 6.8 & 3.3 & 6 & 6.1 & 6.5 & 4.5 \\
\hline $\mathrm{P} 1$ & \multirow{3}{*}{19} & 9 & 3.1 & 0.3 & 2.9 & 2.5 & 2.9 & 1.5 \\
\hline P1 & & 14 & 3.9 & 0.8 & 3.5 & 3.6 & 3.5 & 3.4 \\
\hline $\mathrm{P} 1$ & & 18 & 5 & 2 & 4.9 & 5 & 4.8 & 3.6 \\
\hline
\end{tabular}

\begin{tabular}{|c|c|c|c|c|c|c|c|c|c|c|c|c|c|}
\hline \multicolumn{10}{|c|}{ Table 1: Discharge Calculation } \\
\hline No. & $\begin{array}{c}\text { Width } \\
\mathrm{B} \\
(\mathrm{mm})\end{array}$ & $\begin{array}{c}\mathrm{b}_{1} \\
(\mathrm{~mm})\end{array}$ & $\begin{array}{c}\mathrm{b}_{2} \\
(\mathrm{~mm})\end{array}$ & $\begin{array}{c}\mathrm{h}_{1} \\
(\mathrm{~mm})\end{array}$ & $\begin{array}{c}\mathrm{h}_{2} \\
(\mathrm{~mm})\end{array}$ & $\begin{array}{c}\mathrm{P} \\
(\mathrm{mm})\end{array}$ & $\mathrm{K}_{\mathrm{h}}$ & $\mathrm{h}_{1 \mathrm{e}}$ & $\theta / 2$ & $\mathrm{Crd}_{1}$ & $\mathrm{Crd}_{2}$ & $\mathrm{C}_{\mathrm{td}}$ & $\begin{array}{c}\mathrm{Q}_{\mathrm{t}} \\
(\mathrm{L} / \mathrm{s})\end{array}$ \\
\hline 1. & 960 & 257 & 96 & 18 & 113 & 55 & 0.82232 & 18.8223 & $\begin{array}{c}0.72 \\
89\end{array}$ & $\begin{array}{c}0.613 \\
3\end{array}$ & $\begin{array}{c}0.60 \\
97\end{array}$ & $\begin{array}{c}0.56 \\
31\end{array}$ & 9 \\
\hline 2. & 960 & 257 & 96 & 34 & 129 & 55 & 0.82232 & 34.8223 & $\begin{array}{c}0.72 \\
89\end{array}$ & $\begin{array}{c}0.613 \\
7\end{array}$ & $\begin{array}{c}0.60 \\
92\end{array}$ & $\begin{array}{c}0.56 \\
31\end{array}$ & 14 \\
\hline 3. & 960 & 257 & 96 & 44 & 139 & 55 & 0.82232 & 44.8223 & $\begin{array}{c}0.72 \\
89\end{array}$ & $\begin{array}{c}0.613 \\
7\end{array}$ & $\begin{array}{c}0.60 \\
9\end{array}$ & $\begin{array}{c}0.56 \\
3\end{array}$ & 18 \\
\hline
\end{tabular}




\begin{tabular}{|c|c|c|c|c|c|c|c|c|}
\hline $\begin{array}{c}\text { Downstream } \\
\text { Pier }\end{array}$ & $\begin{array}{c}\text { Angle } \\
(\beta)\end{array}$ & $\begin{array}{c}Q \\
(L / s e c)\end{array}$ & $\begin{array}{l}\text { Sd1' } \\
(\mathrm{cm})\end{array}$ & $\begin{array}{l}\mathrm{Sd} 2^{\prime} \\
(\mathrm{cm})\end{array}$ & $\begin{array}{l}\mathrm{Sd}^{\prime} \\
(\mathrm{cm})\end{array}$ & $\begin{array}{l}\text { Sd4' } \\
(\mathrm{cm})\end{array}$ & $\begin{array}{l}\text { Sd5' } \\
(\mathrm{cm})\end{array}$ & $\begin{array}{l}\mathrm{Sd} 6^{\prime} \\
(\mathrm{cm})\end{array}$ \\
\hline P2 & \multirow{3}{*}{0} & 9 & 4.3 & 0.9 & 3.1 & 2.9 & 3.9 & 1.4 \\
\hline P2 & & 14 & 5.6 & 1.1 & 4 & 4.3 & 4.9 & 3.7 \\
\hline P2 & & 18 & 5.9 & 1.7 & 4.6 & 4.9 & 5.4 & 4.3 \\
\hline $\mathrm{P} 2$ & \multirow{3}{*}{7} & 9 & 3.1 & 0 & 1.7 & 1.9 & 2.4 & 0.9 \\
\hline $\mathrm{P} 2$ & & 14 & 4.2 & 0.5 & 3.5 & 3.4 & 4 & 2.8 \\
\hline P2 & & 18 & 5.2 & 0.8 & 4 & 4.1 & 4.7 & 2.6 \\
\hline $\mathrm{P} 2$ & \multirow{3}{*}{12} & 9 & 2.3 & 0 & 1.4 & 1.5 & 1.8 & 0.5 \\
\hline P2 & & 14 & 3.6 & 0 & 2.9 & 2.7 & 3.3 & 1.9 \\
\hline $\mathrm{P} 2$ & & 18 & 4.5 & 0 & 3.6 & 3.4 & 4 & 1.8 \\
\hline $\mathrm{P} 2$ & \multirow{3}{*}{15} & 9 & 1.8 & 0 & 1 & 1.1 & 1.4 & 0 \\
\hline P2 & & 14 & 3.1 & 0 & 2.4 & 2.1 & 2.6 & 1.2 \\
\hline $\mathrm{P} 2$ & & 18 & 3.3 & 0 & 2.7 & 2.9 & 2.8 & 0 \\
\hline $\mathrm{P} 2$ & \multirow{3}{*}{19} & 9 & 0.6 & 0 & 0.2 & 0 & 0.3 & 0.5 \\
\hline P2 & & 14 & 1.1 & 0 & 1.2 & 1.1 & 1.7 & 0.4 \\
\hline P2 & & 18 & 1.8 & 0 & 1.2 & 1.7 & 1.4 & 0 \\
\hline
\end{tabular}

increased with increase in flowrate. With increase in inclination angle the scour depth is decreased. It can be seen from Tables 2-3 that the values of maximum scour around all sides of both piers are maximum when pier was at $0^{\circ}$ inclination with a flow rate of $18 \mathrm{~L} / \mathrm{sec}$ while minimum when pier was inclined at $19^{\circ}$ with a flow rate of $9 \mathrm{~L} / \mathrm{sec}$. The scour depth value is negligible at downstream side of downstream pier (P2).

\subsection{Relation between Angle of Inclination, Flow Rate and Scouring Pattern}

Fig. 5(a-c) shows the variation of longitudinal scour profile by varying inclination angle at a flow rate of 9 , 14 and $18 \mathrm{~L} / \mathrm{sec}$ respectively of the upstream pier (P1). The Upstream side and downstream side of Pier (P1) shows that the scouring is maximum at an inclination angle of $0^{\circ}$ with $18 \mathrm{~L} / \mathrm{sec}$. As the angle of inclination is increased to $7^{\circ}$ the scouring is reduced. From the experimental results it is observed that the longitudinal scouring goes on decreasing as the angle of inclination increases further and becomes minimum when the angle of inclination is $19^{\circ}$ (with vertical) with $9 \mathrm{~L} / \mathrm{sec}$. The main reason for this is when pier is at $0^{\circ}$ with vertical, the strong horseshoe vortices are created which causes maximum scouring at upstream side of pier. When angle of inclination is increased, the strength of horseshoe vortices becomes weak which decrease the scouring. The scouring at downstream side is lesser than upstream side due to transportation of erosive material and weaker horse-shoe vortices.

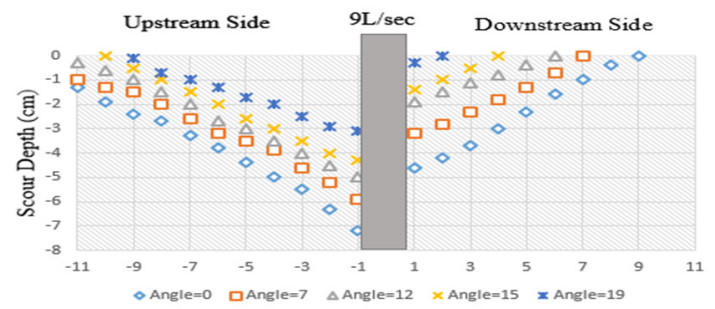

Fig 5(a): Longitudinal Scour Profile of Upstream Pier at 9L/Sec.

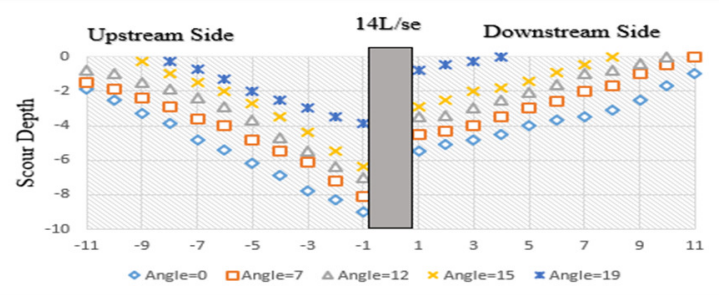

Fig 5(b): Longitudinal Scour Profile of Upstream Pier at 14L/Sec.

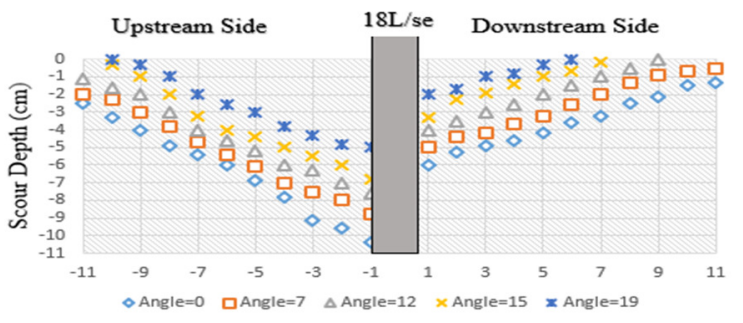

Fig 5(c): Longitudinal Scour Profile of Upstream Pier at 18L/Sec. 
Fig. 6(a-c) show the variation of scouring pattern by varying inclination angle around downstream pier (P2) at a flow rate of 9,14 and $18 \mathrm{~L} / \mathrm{sec}$ respectively. From experiments it is observed that the scour depth at the upstream side is maximum at $0^{\circ}$ with flow rate $18 \mathrm{~L} / \mathrm{sec}$ and minimum at $19^{\circ}$ with flow rate $9 \mathrm{~L} / \mathrm{sec}$. Whereas, the scouring at the downstream side is negligible because of the weak horseshoe vortices and also the transportation of erosive material cause aggradation at the downstream side.

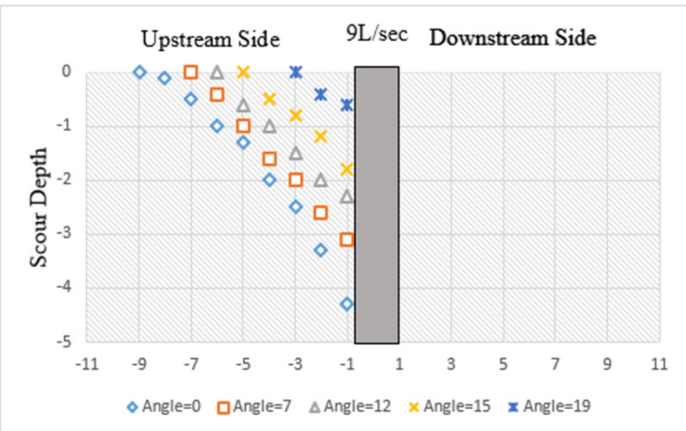

Fig. 6(a): Longitudinal Scour Profile of Upstream Pier at 9L/Sec.

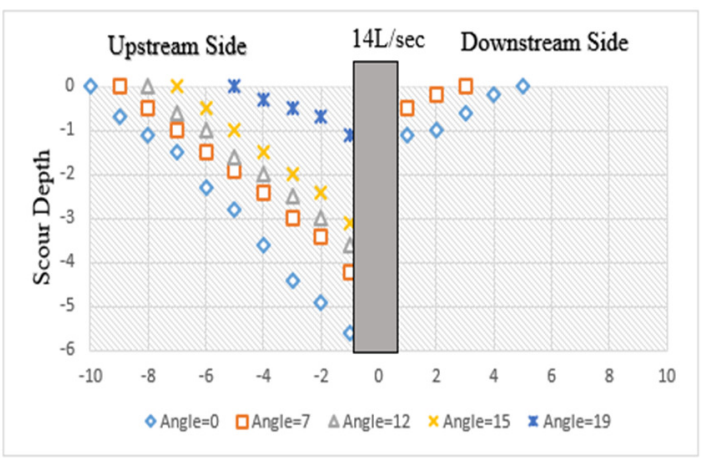

Fig. 6(b): Longitudinal Scour Profile of Upstream Pier at 14L/Sec.

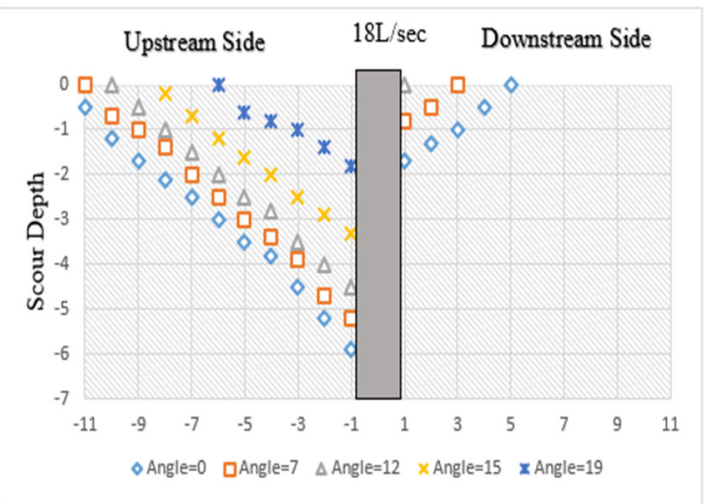

Fig. 6(c): Longitudinal Scour Profile of Upstream Pier at $18 \mathrm{~L} / \mathrm{Sec}$.

\subsection{Variation of Scour Hole Pattern Around Upstream Pier with Angle of Inclination}

Fig. 7 represents the variation of the 3D-scouring pattern generated by using Surfer (16) around upstream pier $\left(\mathrm{P}_{1}\right)$ with inclination angle $0^{\circ}, 7^{\circ}, 12^{\circ}$, $15^{\circ}$ and $19^{\circ}$ at flow rate 9,14 , and $18 \mathrm{~L} / \mathrm{sec}$ respectively. The flow is along $\mathrm{x}$-axis. The maximum scour depth and scour hole is generated when the pier is at $0^{\circ}$, with an increase in the angle of inclination the scour depth and scour hole is reduced.

Fig. 7(a-c) shows the scouring pattern around upstream pier $\left(\mathrm{P}_{1}\right)$ at angle of inclination $0^{\circ}$ and flow rate 9,14 , and $18 \mathrm{~L} / \mathrm{sec}$ respectively. These geometries represent that scour depth \& scour area were maximum at $0^{\circ}$ with flow rate $18 \mathrm{~L} / \mathrm{sec}$. At downstream of the pier, the deposition has occurred with lesser scouring is lesser as compared to upstream side.

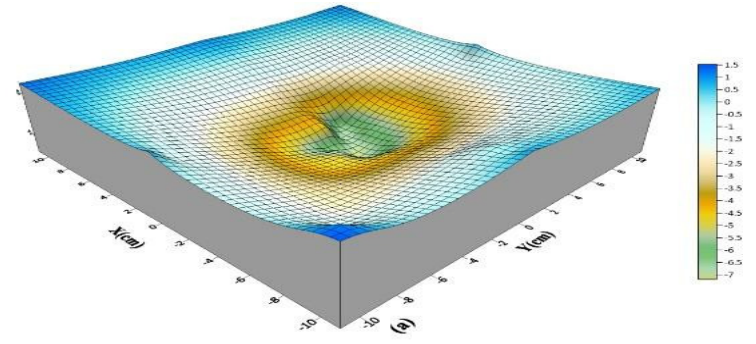

Fig. 7(a): The Scour and Deposition Pattern around Pier $\left(\mathrm{P}_{1}\right)$ at angle $0^{\circ}$ and flowrate $9 \mathrm{~L} / \mathrm{Sec}$.

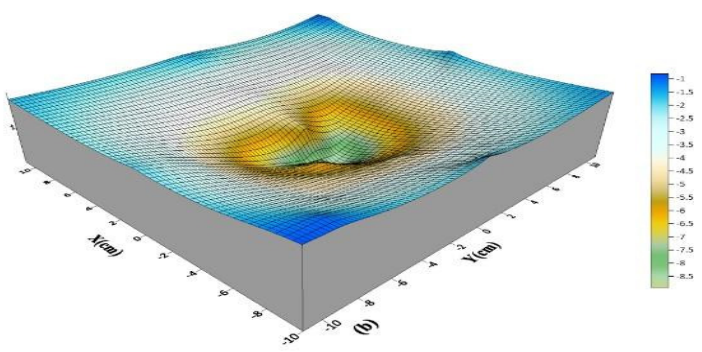

Fig. 7(b): The Scour and Deposition Pattern around Pier $\left(\mathrm{P}_{1}\right)$ at angle $0^{\circ}$ and flowrate $14 \mathrm{~L} / \mathrm{Sec}$.

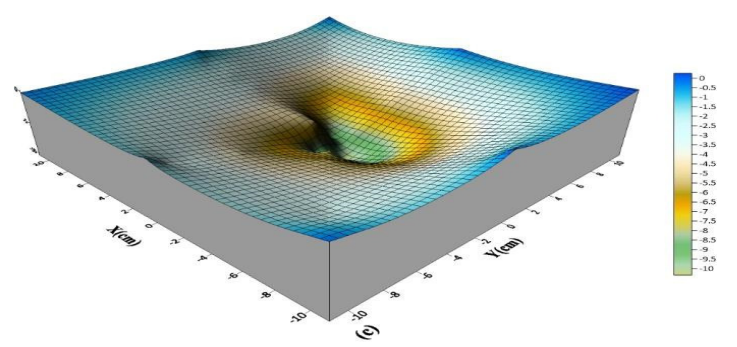

Fig. 7(c): The Scour and Deposition Pattern around Pier $\left(\mathrm{P}_{1}\right)$ at angle $0^{\circ}$ and flowrate $18 \mathrm{~L} / \mathrm{Sec}$. The green area denotes maximum pattern. 
Fig. 7(d-f) shows the scouring pattern variation at $7^{\circ}$ and flow rates 9,14 , and $18 \mathrm{~L} / \mathrm{sec}$ respectively. The scour area and depth were greater in the case of $7^{\circ}$ with flow rate $18 \mathrm{~L} / \mathrm{sec}$ while the scour depth was smaller in case of $7^{\circ}$ with flow rate of $9 \mathrm{~L} / \mathrm{sec}$ respectively.

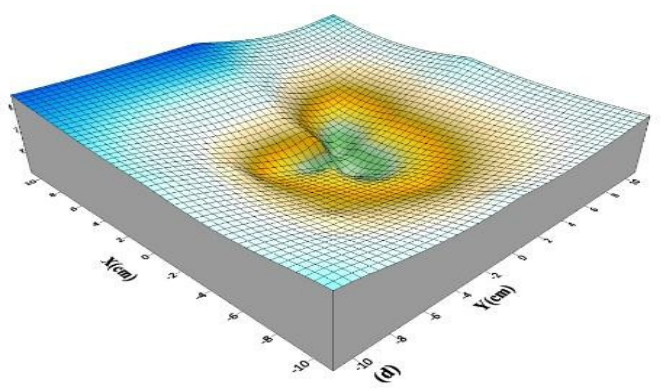

Fig. 7(d): The Scour and Deposition Pattern around Pier $\left(P_{1}\right)$ at angle $7^{\circ}$ and flowrate $9 \mathrm{~L} / \mathrm{Sec}$.

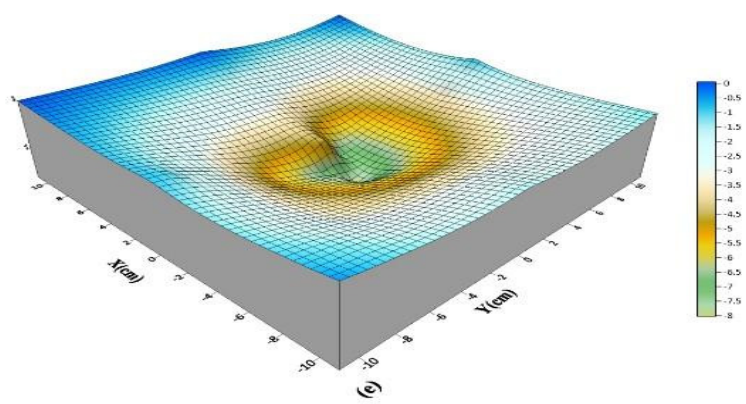

Fig. 7(e): The Scour and Deposition Pattern around Pier $\left(P_{1}\right)$ at angle $7^{0}$ and flowrate $14 \mathrm{~L} / \mathrm{Sec}$

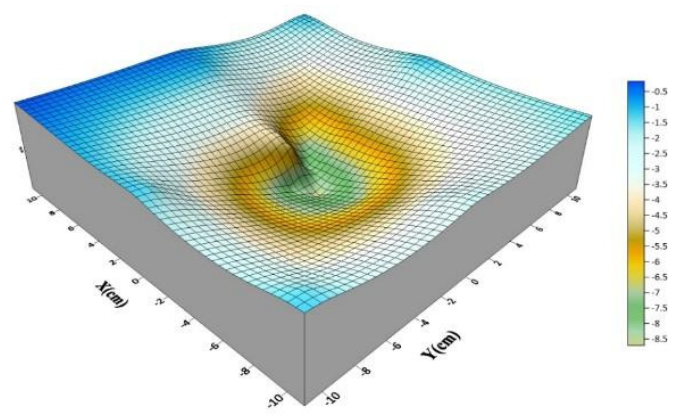

s

Fig. 7(f): The Scour and Deposition Pattern around Pier $\left(\mathrm{P}_{1}\right)$ at angle $7^{0}$ and flowrate $18 \mathrm{~L} / \mathrm{Sec}$

The green area denotes maximum Scouring Pattern

The Fig. 7(g-i)) represent the scour pattern variation at $12^{\circ}$ and flow rate 9,14 , and $18 \mathrm{~L} / \mathrm{sec}$ respectively. These figures show the scour depth and scour area is decreased further as angle of inclination is increased to $12^{\circ}$. While the scour depth and scour area are increased with increase in flow rate.

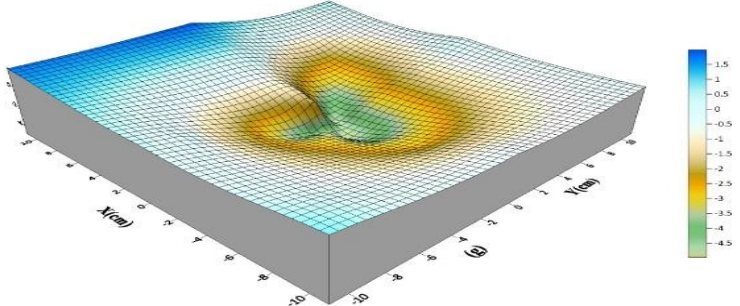

Fig. $7(\mathrm{~g})$ : The Scour and Deposition Pattern around Pier $\left(\mathrm{P}_{1}\right)$ at angle $12^{\circ}$ and flowrate $9 \mathrm{~L} / \mathrm{Sec}$.

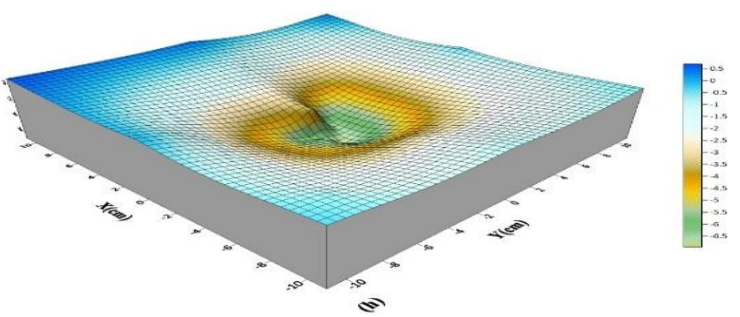

Fig. 7(h): The Scour and Deposition Pattern around Pier $\left(\mathrm{P}_{1}\right)$ at angle $12^{\circ}$ and flowrate $14 \mathrm{~L} / \mathrm{Sec}$.

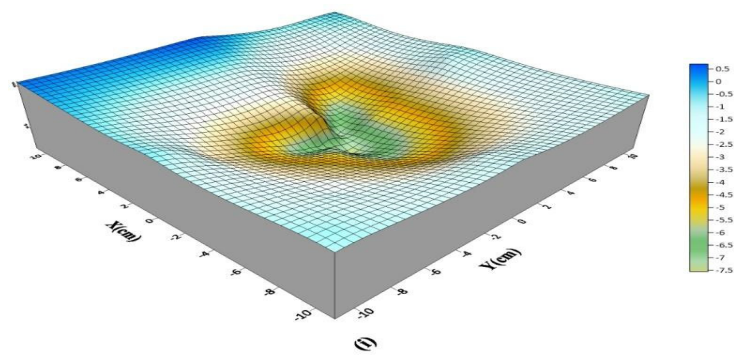

Fig. 7(i): The Scour and Deposition Pattern around Pier $\left(\mathrm{P}_{1}\right)$ at angle $12^{\circ}$ and flowrate $18 \mathrm{~L} / \mathrm{Sec}$.

The green area denotes maximum Scouring Pattern

Fig. 7(j-o) represent scour pattern at angle of inclination $15^{\circ}$ and $19^{\circ}$ and flow rate 9,14 , and $18 \mathrm{~L} / \mathrm{sec}$ respectively. These figures show scour area and depth around pier is reduced as angle of inclination is increased to $15^{\circ}$. It becomes minimum at an angle of inclination $19^{\circ}$.

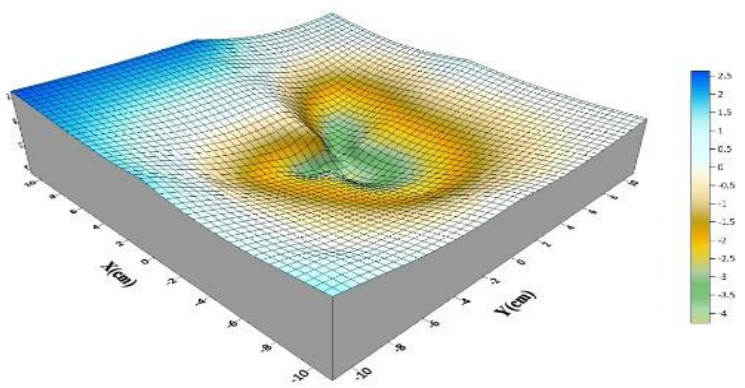

s

Fig. 7(j): The Scour and Deposition Pattern around Pier $\left(\mathrm{P}_{1}\right)$ at angle $15^{\circ}$ and flowrate $9 \mathrm{~L} / \mathrm{Sec}$. 


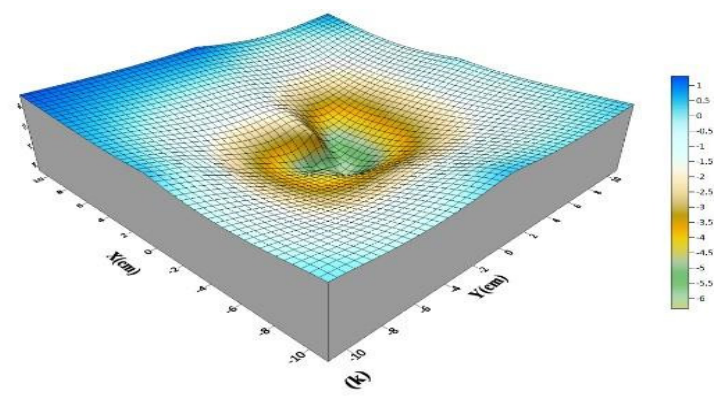

Fig. 7(k): The Scour and Deposition Pattern around Pier $\left(P_{1}\right)$ at angle $15^{\circ}$ and flowrate $14 \mathrm{~L} / \mathrm{Sec}$.

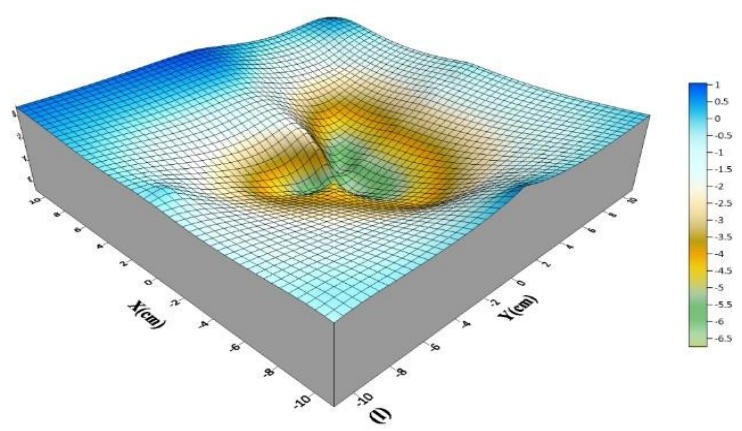

Fig. $7(\mathrm{I})$ : The Scour and Deposition Pattern around Pier $\left(\mathrm{P}_{1}\right)$ at angle $15^{\circ}$ and flowrate $18 \mathrm{~L} / \mathrm{Sec}$. The green area denotes maximum scouring pattern
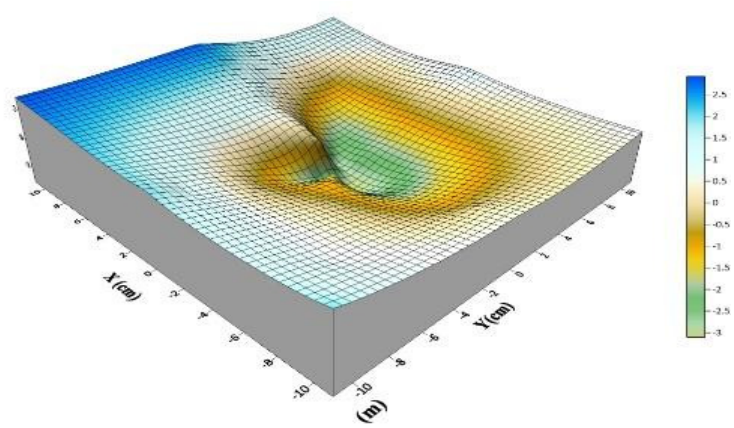

Fig. 7(m): The Scour and Deposition Pattern around Pier $\left(P_{1}\right)$ at angle $19^{\circ}$ and flowrate $9 \mathrm{~L} / \mathrm{Sec}$.

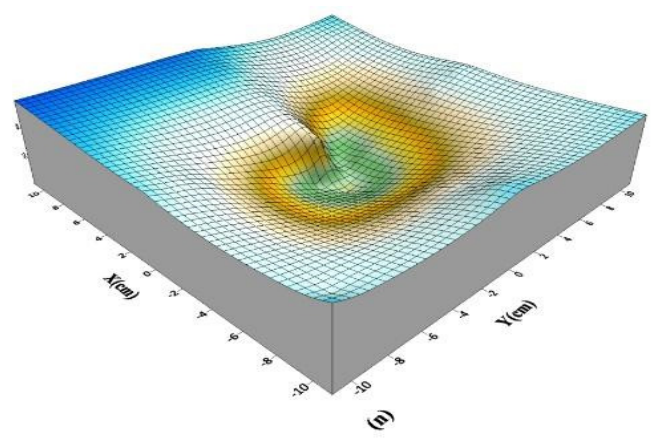

Fig. 7(n): The Scour and Deposition Pattern around Pier $\left(P_{1}\right)$ at angle $19^{\circ}$ and flowrate $14 \mathrm{~L} / \mathrm{Sec}$.

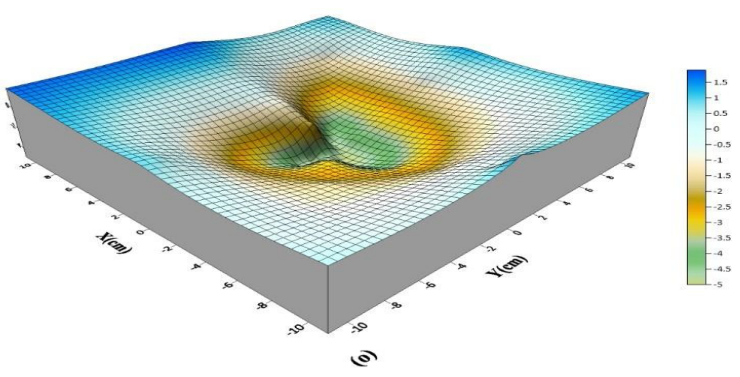

Fig. 7(0): The Scour and Deposition Pattern around Pier

$\left(P_{1}\right)$ at angle $19^{\circ}$ and flowrate $18 \mathrm{~L} / \mathrm{Sec}$.

The green area denotes maximum Scouring Pattern

\subsection{Variation of Scour Hole Pattern Around Downstream Pier with Angle of Inclination}

Fig. 8 represents the variation of scouring pattern around downstream pier at angle of inclination $0^{\circ}, 7^{\circ}, 12^{\circ}, 15^{\circ}$ and $19^{\circ}$ and flow rate 9,14 , and $18 \mathrm{~L} / \mathrm{sec}$ respectively. The scour area and depth are greater in case of $0^{\circ}$ as shown in Fig. 8(a-c) while it decreases as angle of inclination is increased to $7^{\circ}$ and $12^{\circ}$ as shown in Fig. 8(d-i). The scour area and depth become minimum at angle of inclination $19^{\circ}$ as shown in Fig. $8(\mathrm{~m}-\mathrm{o})$. In case of downstream pier deposition occurred at downstream side of $\operatorname{pier}\left(\mathrm{P}_{2}\right)$ because the scouring material form $\left(\mathrm{P}_{1}\right)$ is transported to downstream side of pier $\left(\mathrm{P}_{2}\right)$.

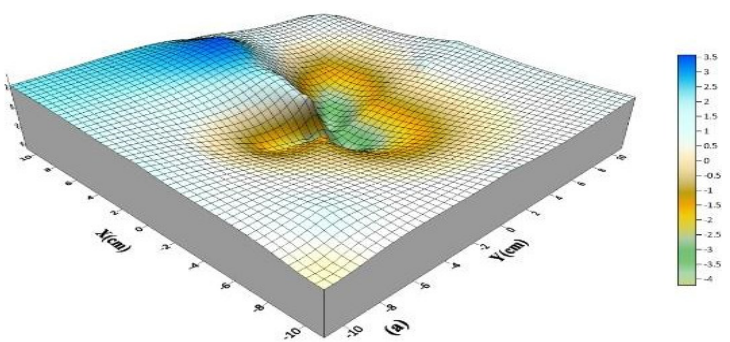

Fig. 8(a): The Scour and Deposition Pattern around Pier $\left(\mathrm{P}_{2}\right)$ at angle $0^{\circ}$ and flowrate $9 \mathrm{~L} / \mathrm{Sec}$.

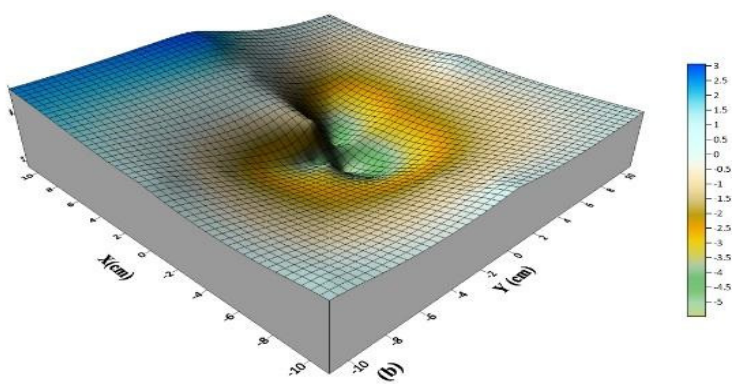

Fig. 8(b): The Scour and Deposition Pattern around Pier $\left(\mathrm{P}_{2}\right)$ at angle $0^{\circ}$ and flowrate $14 \mathrm{~L} / \mathrm{Sec}$. 


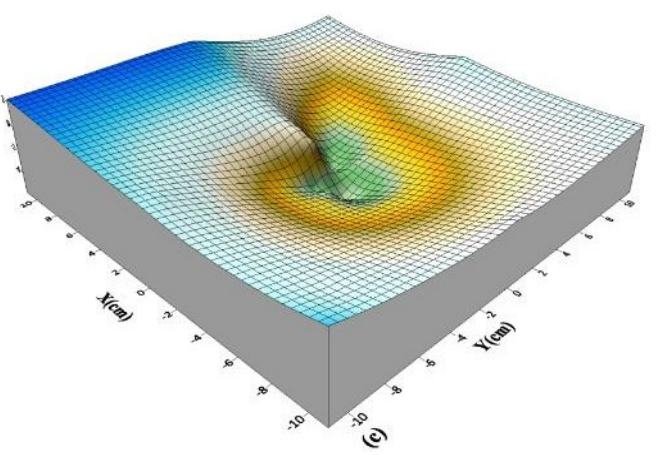

Fig. 8(c): The Scour and Deposition Pattern around Pier $\left(\mathrm{P}_{2}\right)$ at angle $0^{\circ}$ and flowrate $18 \mathrm{~L} / \mathrm{Sec}$. The green area denotes maximum scouring pattern.

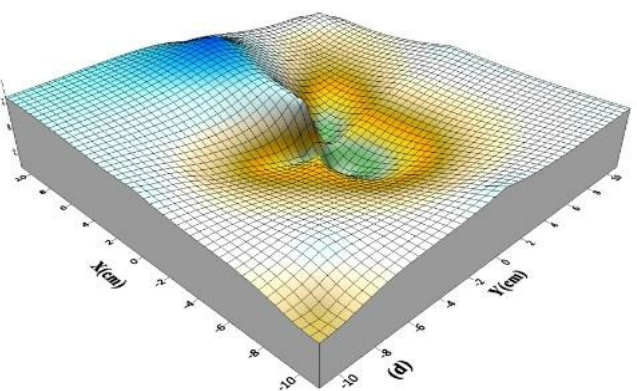

Fig. 8(d): The Scour and Deposition Pattern around Pier $\left(P_{2}\right)$ at angle $7^{\circ}$ and flowrate $9 \mathrm{~L} / \mathrm{Sec}$.
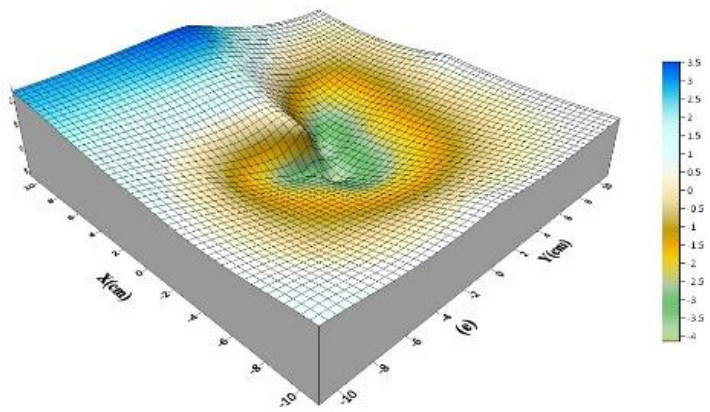

Fig. 8(e): The Scour and Deposition Pattern around Pier $\left(\mathrm{P}_{2}\right)$ at angle $7^{\circ}$ and flowrate $14 \mathrm{~L} / \mathrm{Sec}$
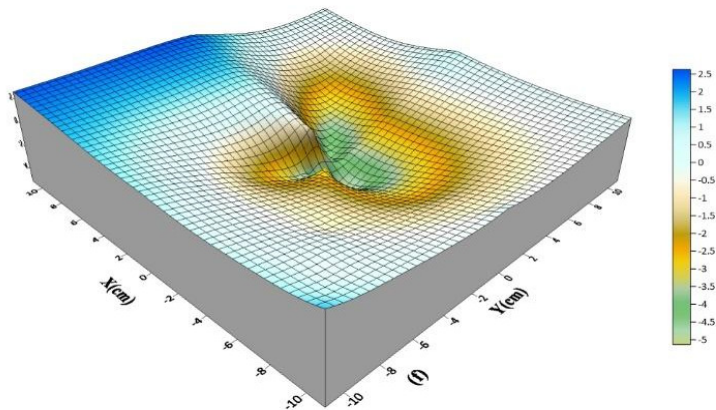

Fig. 8(f): The Scour and Deposition Pattern around Pier $\left(\mathrm{P}_{2}\right)$ at angle $7^{\circ}$ and flowrate $18 \mathrm{~L} / \mathrm{Sec}$

The green area denotes maximum scouring pattern

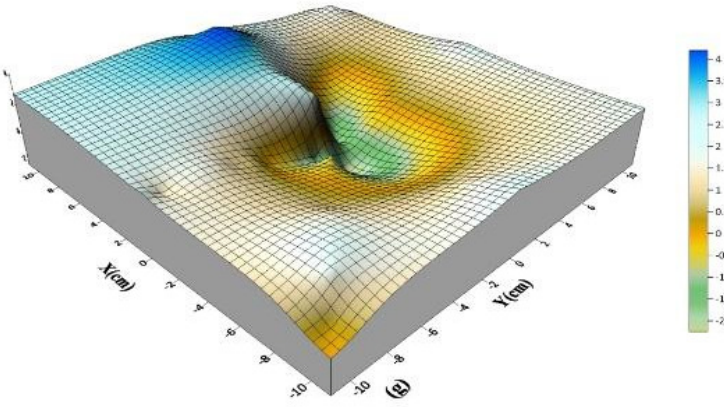

Fig. 8(g): The Scour and Deposition Pattern around Pier $\left(\mathrm{P}_{2}\right)$ at angle $12^{\circ}$ and flowrate $9 \mathrm{~L} / \mathrm{Sec}$.

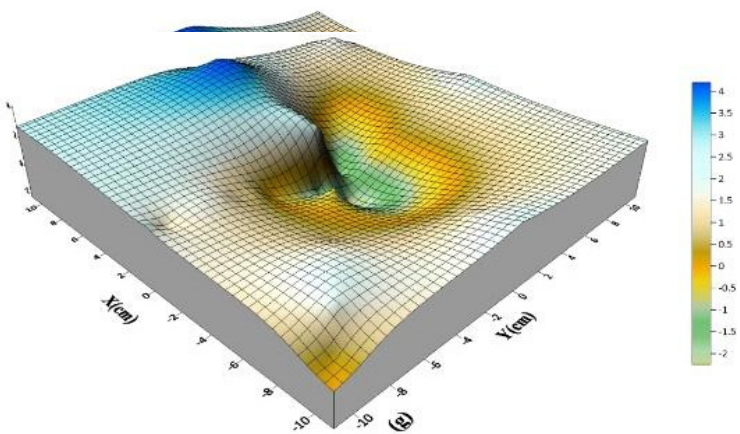

Fig. 8(h): The Scour and Deposition Pattern around Pier $\left(\mathrm{P}_{2}\right)$ at angle $12^{\circ}$ and flowrate $14 \mathrm{~L} / \mathrm{Sec}$.

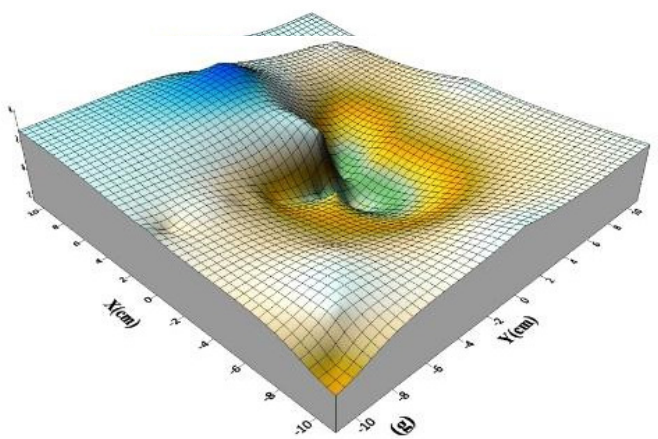

Fig. 8(i): The Scour and Deposition Pattern around Pier $\left(\mathrm{P}_{2}\right)$ at angle $12^{\circ}$ and flowrate $18 \mathrm{~L} / \mathrm{Sec}$. The green area denotes maximum Scouring pattern

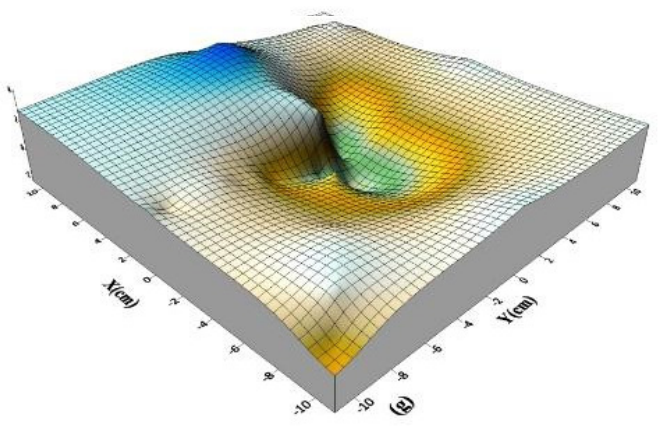

Fig. 8(j): The Scour and Deposition Pattern around Pier $\left(\mathrm{P}_{2}\right)$ at angle $15^{\circ}$ and flowrate $9 \mathrm{~L} / \mathrm{Sec}$. 


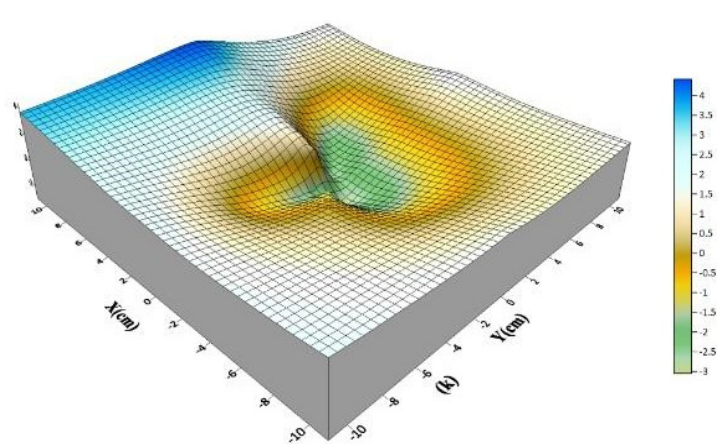

Fig. 8(k): The Scour and Deposition Pattern around Pier $\left(\mathrm{P}_{2}\right)$ at angle $15^{\circ}$ and flowrate $14 \mathrm{~L} / \mathrm{Sec}$.

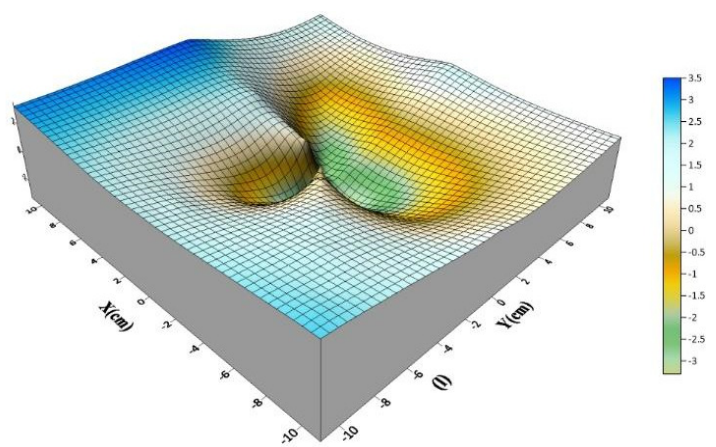

Fig. 8(I): The Scour and Deposition Pattern around Pier $\left(\mathrm{P}_{2}\right)$ at angle $15^{\circ}$ and flowrate $18 \mathrm{~L} / \mathrm{Sec}$. The green area denotes maximum scouring pattern

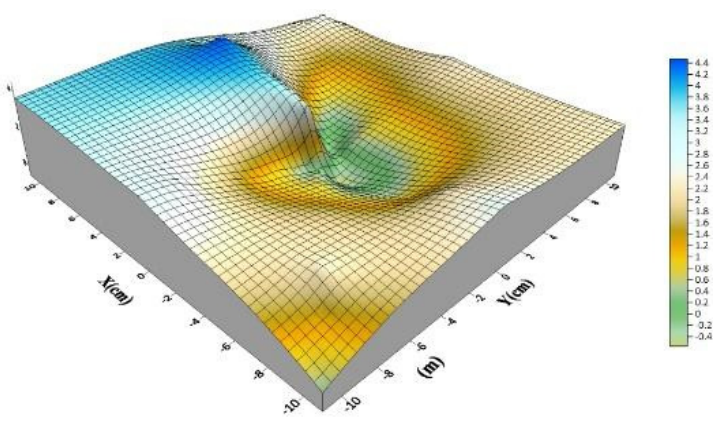

Fig. 8(m): The Scour and Deposition Pattern around Pier $\left(\mathrm{P}_{2}\right)$ at angle $19^{\circ}$ and flowrate $9 \mathrm{~L} / \mathrm{Sec}$.

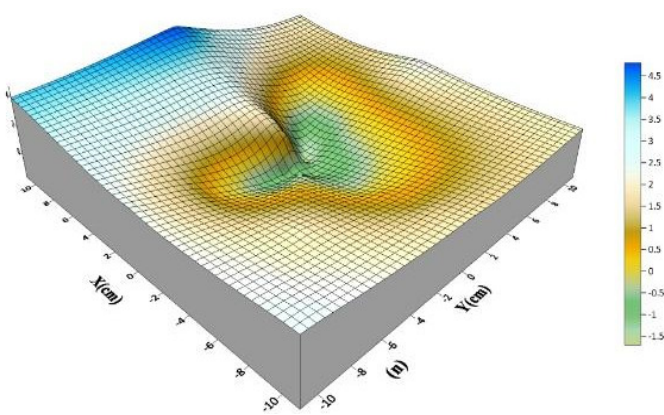

Fig. 8(n): The Scour and Deposition Pattern around Pier $\left(P_{2}\right)$ at angle $19^{\circ}$ and flowrate $14 \mathrm{~L} / \mathrm{Sec}$.

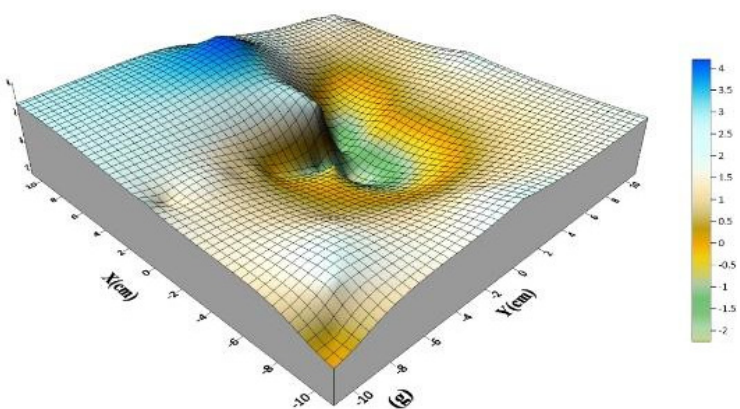

Fig. 8(0): The Scour and Deposition Pattern around Pier $\left(\mathrm{P}_{2}\right)$ at angle $19^{\circ}$ and flowrate $18 \mathrm{~L} / \mathrm{Sec}$.

The green area denotes maximum scouring pattern

\section{CONCLUSIONS}

Basic purpose of this study was to investigate the local scouring around pair of inclined bridge piers and comparison between scouring pattern of both piers. Upstream and downstream rectangular bridge piers were used at inclination angle of $0^{\circ}, 7^{\circ}, 12^{\circ}, 15^{\circ}$ and $19^{\circ}$ with vertical.it is concluded that:

(i) The scour depth and scour area are reduced with increase in pier inclination, because increasing inclination would weaken the strength of downward horseshoe vortices which reduces the scour depth. The value of scour depth is maximum at $0^{\circ}$ while minimum at $19^{\circ}$.

(ii) There is direct relation between flow rate and scour depth. The scour depth is minimum at $9 \mathrm{~L} / \mathrm{sec}$ while it becomes maximum at $18 \mathrm{~L} / \mathrm{sec}$.

(iii) The scour depth at downstream side is lesser as compared to upstream side in case of both piers. This is due to weaker strength of horse-shoe vortices at downstream side and area with lower velocity at downstream side is resulted.

(iv) At downstream side of downstream pier $\left(\mathrm{P}_{2}\right)$ the value of scour depth is relatively small because of aggradation and transportation of erosive material.

(v) So, the inclined pier configuration is reliable for reduction of scouring around piers. The value of inclination angle of piers should be adjusted according to structural aspects.

\section{ACKNOWLEDGEMENT}

The author would especially like to thank the Lab Engr. Mujahid Iqbal and staff of Hydraulic 
Laboratory, Department of Civil Engineering, University of Engineering and Technology, Taxila, Pakistan, for their funding and support.

\section{REFERENCES}

[1] Karimi N, Heidarnejad M, Masjedi A., "Scour depth at inclined bridge piers along a straight path: A laboratory study", Engineering, Science and Technology - an International Journal, Vol. 20, No 4, pp. 1302-1307, 2017.

[2] Briaud J-L, Ting F.C.K, Chen H.C, Gudavalli R, Perugu S, Wei G., "SRICOS:Prediction of Scour Rate in Cohesive Soils at Bridge Piers", Journal of Geotechnic Geoenvironmental Engineering, Vol. 125,No.4,pp.237-46,1999.

[3] Shirhole A.M., Holt, R.C., "Planning for a Comprehensive Bridge Safety Program", Transportation Research Record, Vol. 1290, pp. 39-50, USA, 1991.

[4] Bozkus Z, Asce M, Yildiz O. "Effects of Inclination of Bridge Piers on Scouring Depth", Journal of Hydraulic Engineering, Vol. 130 ,No.8,August 2004.

[5] Heidarnejad M, Bajestan MS, Masjedi A."The Effect of Slots on Scouring Around Piers in Different Positions of 180-Degrees Bends", World Applied Science Journal, Vol. 8, No.7, pp 892-9, 2010.

[6] Kumar A, Kothyari UC, Ranga Raju KG, "Flow structure and scour around circular compound bridge piers- A review". Journal of HydroEnvironment Research, Vol. 6, No.4 ,pp 251-65 ,2012.

[7] Debnath K, Chaudhuri S., "Laboratory experiments on local scour around cylinder for clay and clay-sand mixed beds". Engineering Geology, Vol. 111,No 1-4, pp 51-61,2010.

[8] Guo J, Kerenyi K, Shan H, Xie Z, Zhai Y, Zhao L., "Time-Dependent Scour Depth under BridgeSubmerged Flow". Scour Erosion, Vol. 10514,2010 .

[9] Kitsikoudis V, Kirca VSO, Yagci O, Celik MF., "Clear-water scour and flow field alteration around an inclined pile", Coastal Engineering Journal, Vol. 129, pp. 59-73,2017.

[10]Zhao M, Cheng L, Zang Z., "Experimental and numerical investigation of local scour around a submerged vertical circular cylinder in steady currents", Coastal Engineering Journal, Vol. 57,No 8, pp 709-21, 2010.

[11] Vaghefi M, Ghodsian M, Salimi S., "The effect of circular bridge piers with different inclination angles toward downstream on scour", Sadhana Academy Proceeding in Engineering Science, Vol. 41, No. 1, pp 75-86, 2016.

[12] Mohammed YA, Saleh YK, Ali AAM, "Experimental investigation of local scour around multi-vents bridge piers", Alexandria Engineering Journal, Vol. 54, No. 2, pp. 197203, 2015.

[13] Hamidi A, Siadatmousavi SM, "Numerical simulation of scour and flow field for different arrangements of two piers using SSIIM model", Ain Shams Engineering Journal, 2017.

[14]Guan D, Chiew YM, Wei M, Hsieh SC."Characterization of horseshoe vortex in a developing scour hole at a cylindrical bridge pier", International Journal Sediment Research, pp 1-7, 2018.

[15] Moussa AMA."Evaluation of local scour around bridge piers for various geometrical shapes using mathematical models", Ain Shams Engineering Journal, 2017.

[16] Murtaza G, Hashmi HN, Naeem UA, Khan D, Ahmad N."Effect of Bridge Pier Shape on Scour Depth at Uniform Single Bridge Pier", Mehran University Research Journal of Engineering and Technology, Vol. 37,No 3,pp 539-44,2018.

[17]Elnikhely EA."Minimizing scour around bridge pile using holes", Ain Shams Engineering Journal, Vol. 8, No 4, pp 499-506, 2016.

[18] Ghani U, Ali S,"Modelling the Flow Structure in Local Scour Around Bridge Pier", Mehran University Research Journal of Engineering and Technology, Vol. 33, No 4,2016.

[19] Amir M, Hashmi HN, Baloch M, Ehsan MA, Muhammad U, Ali Z., "Experimental Investigation of Channel Bank Vegetation on Scouring Characteristics Around A Wing Wall Abutment". Mehran University Reserach Journal of Engineering and Technology, Vol. 23, No. 1, pp. 15-21,2018.

[20] Yanmaz, A.M, Omer, K, "Time-Wise Variation of Scouring at Bridge Abutments", Volume 32, No. 3, pp. 199-213, 2007. 
[21]Chiew, Y.M., and Melville, B.W., "Local Scour Around Bridge Piers", Journal of Hydraulic Research, Vol. 25, No. 1, pp. 15-26, Netherlands, 1999.

[22]Reca J., Morillas MT, López JG, Jan C."Discussion of " Design and Calibration of compound crested weir ", Journal of Hydraulic Engineering, Vol. 132 , No 8, pp 86871,(June).2016. 